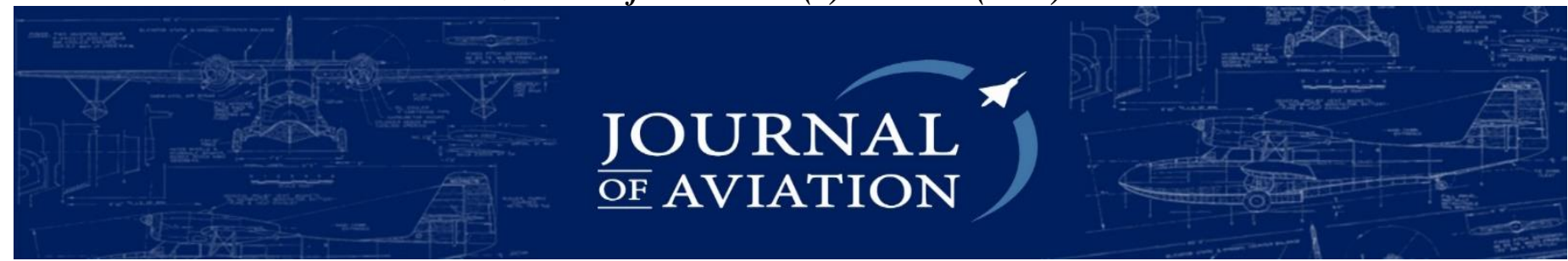

\title{
Üniversitede Havacılık Bölümlerinde Okuyan Öğrencilerin Meslek Seçiminde Etkili Olan Faktörlerin Analizi
}

\author{
Gülaçtı ŞEN* (D) \\ İstanbul Esenyut Üniversitesi, Ulaştırma Bölümü, İstanbul, Türkiye
}

\begin{abstract}
Özet
Meslek seçimi, öğrencilerin gelecek planlarını belirlemede, mutlu olmalarında ve topluma yararlı birey olarak yaşamlarını sürdürmelerinde çok önemli bir etkiye sahiptir. Günümüzde havacılık sektörünün hızlı gelişimiyle birlikte üniversitelerde havacılık bölümlerinin hızla açılmaya başlaması, konunun önemini ortaya koymaktadır. Bu doğrultuda çalışmanın amacı, üniversitelerin havacılık bölümlerinde öğrenimlerini sürdüren öğrencilerin meslek seçiminde etkili olduğu düşünülen etmenleri incelemektir. Çalışmada araştırmanın örneklemini üniversitede havacıllk bölümlerine yeni kayıt yaptıran ve rastgele örnekleme tekniği ile seçilen 253 öğrenci oluşturmuştur. Verilerin toplanmasında anket formu kullanılmıştır. Öğrencilerin \%35,6’sı kadın (90), \%64,4’ü (163) erkektir. Öğrencilerin \% 76.7'sinin ilk tercihi havacılık bölümüdür. Havacıllı̆̆ tercih nedenleri ile ilgili olarak öğrencilerin 7'li Likert skalasına göre puan vermeleri istenmiştir. Buna göre havacılık sektöründe kariyer yapma isteği (ortalama 6,53 puan), havacıllğın saygın bir meslek olduğunu düşünme $(6,52)$, havacılığa ilgi duyma $(6,45)$, ekip çalışmasını sevme $(6,18)$, yeteneklerinin havacılığa uygun olduğunu düşünme $(5,81)$ ilk beş sırada yer alan etmenlerdir.
\end{abstract}

Anahtar Kelimeler: Havacılık eğitimi, meslek seçimi, mesleki rehberlik

\section{Analysis of Factors Affecting the Choice of Profession of Students Studying in Aviation Departments in University}

\begin{abstract}
Choosing a profession has a very important role on students for determining the future plans, being happy and maintaining their lives as individuals who are beneficial to the society. Nowadays, with the rapid development of the aviation sector, the rapid opening of the aviation departments in universities reveals the importance of the subject. The aim of this study is to examine the factors that are thought to be effective in the choice of profession of students studying in aviation departments of universities. The sample of the study consists of 253 students who are newly enrolled in the aviation departments of the university and random sampling technique. Survey form is used for collecting informations. \%35,6

* Sorumlu Yazar/Corresponding Author: Öğr. Görv. Gülaçtı ŞEN gulactisen@esenyurt.edu.tr

This is an open access article distributed under the terms of the Creative Commons Attiribution 4.0 International Licence

Alıntı/Citation : ŞEN, G. (2019). Üniversitede Havacıllk Bölümlerinde Okuyan Öğrencilerin Meslek Seçiminde Etkili Olan Faktörlerin Analizi. Journal of Aviation, 3 (2), 122-131. DOI: $10.30518 /$ jav.637794
\end{abstract}


(90) are female and \%64,4 (163) are male students. Aviation Department is the first choice of $\% 76,4$ of the students. The students were asked to score on the 7-point Likert scale for the reason of aviation preference. First five factors are; to have a career in aviation sector (apx. 6,53 points), thinking that aviation is a respected profession $(6,52)$, interested in aviation $(6,45)$, loving teamwork $(6,18)$, thingkin tat their abilities are appropriate to aviation $(5,81)$ according to their selections.

Keywords: Aviation education, career choice, career counseling

\section{Giriş}

Meslek seçimi bireyin tüm yaşamını etkileyen en önemli kararlardan biridir. Bu sürecin bilinçli olarak yapılması hem birey hem de toplum açısından, ülkenin ve dünyanın geleceği açısından büyük önem taşımaktadır. Çünkü meslek seçimini yanlış yapan ve seçtiği meslekte huzursuz olan birey, verimli olamaz ve topluma yarar sağlayamaz. Birey, başarılı olacağını düşündügü, kişiliğine, ilgi ve yeteneklerine uygun mesleği seçme ve bu seçimi yaparken bilişsel, akılc1, ileri görüşlü olmalıdır. Kendi yetenekleri ile seçeceği mesleğin niteliklerini iyi analiz etmelidir.

Meslek seçimi ile birey, belirli bir yaşam biçimini seçmektedir. Bu yaşamı değerli kılacak olan her şey, doğru meslek seçiminin yapılmasıyla mümkündür. Yeteneklerime uygun mesleği seçmiş ve seçmemiş olan bireyler arasında büyük farklar olduğu ortadadır. Yeteneklerine uygun mesleği seçmiş bireyler, işini severek yapan, mesleğinde ilerleyen ve topluma hizmet ederek yaşamlarını sürdürür. Yeteneklerine uygun mesleği seçmemiş bireyler ise seçtikleri meslekte mutlu olmayan, çalışmaya karşı isteksiz, yeniliğe kapalı, kendini geliştirmeyen bireylerdir [1]. En ideal meslek seçimi, bireyin başarılı ve iyi bir yaşam sürdürmesine, bu süreci başarılı bir şekilde devam ettirebilmesine ve toplumun belli ihtiyacinı karşılamasına imkân vermelidir [2].

Meslek seçiminin bir gelişim süreci olduğunu savunan gelişim kuramcılarına göre birey, işe girme çağına gelene kadar olgunlaşan ve geri dönülmesi çok mümkün olmayan davranış biçimlerinin birikimi sonucunda, ilgi duyduğu bir mesleğe yönelmektedir [3]. Ancak bu süreçte bireyin yöneldiği mesleği seçmesi süreci, kişinin gerçek işini seçiminden çok önce başlamaktadır. Bireyin geçmişi, sosyo-demografik özellikleri, iş avantajları, yetenekleri, ilgi alanları ve kişilik özellikleri meslek seçimini etkileyen en önemli etkenler olarak siralanabilir [4].

Literatürde meslek seçimine etki eden faktörler farklı yazarlar tarafından araştırma konusu olmuştur. Bireyin meslek seçimini etkileyen en etkili faktörlerin; kişinin kişisel özellikleri, geçmişi, bilgi birikimi, sahip olduğu değerleri, ilgileri, inançları ile aile yapısı, yaşam koşulları, ülkenin kültürel ve sosyo-ekonomik durumu olduğu görülmektedir [5]. Bunlara ek olarak cinsiyet [3], meslekten elde edilen gelir, kariyer imkânları, iş güvencesi de meslek seçimini etkileyen önemli etmenler arasındadir [6].

Vurucu'nun Super (1990)'den aktardığına göre meslek seçimini etkileyen etmenler aşağıdaki gibidir [3]:

- Biyolojik Etmenler: Bireyin fiziksel özellikleri, cinsiyet, beden yapısı, görme ve işitme durumu v.b.

- Sosyolojik Etmenler: Duyguları, değerleri, aile ile ilişkileri, bağlı olduğu arkadaş çevresinin beklentileri ve baskıları, ailenin sosyal düzeyi, yakın ilişki kurulan öteki kişiler.

- Psikolojik ya da Kişisel Etmenler: Bireyin ihtiyaçları, duyguları, tutumları, değerleri, ilgileri ve yetenekleri.

- Ekonomik Etmenler: Ailenin ekonomik düzeyi, çevrenin ya da ülkenin genel ekonomik durumu, otomasyon ve teknik gelişmeler, bunların toplumun insan ihtiyacı üzerindeki etkileri.

- Politik Etmenler: Mesleğe girme olanakları, iş bulma olanakları, değişik eğitim ve yetişme firsatları, v.b.

- Şans ile ilgili Etmenler: Doğal afetler, işleri ve işyerlerini etkileyen beklenmedik olaylar, iç ve dış savaşlar, v.b.

Meslek seçiminde, kişinin üzerinde etkili olan faktörlerin biyolojik, sosyolojik, psikolojik ve kişisel, ekonomik, politik ve şans ile ilgili etmenler 
gibi çeşitli olduğu görülmektedir. Başka bir çalışmada bir mesleğin bilge seçiminde üç geniş faktör ortaya konulmaktadır. Bunlar [7]:

1. Kendinizi net bir şekilde anlayabilme; yeteneklerinizi, ilgilerinizi, amaçlarınızı, sınırlarınızı ve sebeplerinizi açık bir şekilde ifade edilebilmelidir.

2. İhtiyaçlar, başarının koşulları, avantaj ve dezavantajları, farklı çalışma alanlarında fırsatlar, koşullar, maaş açık bir şekilde ifade edilebilmelidir.

3. Gerçeklerin bu iki grubun ilişkileriyle muhakeme edilmesi gerekmektedir.

Meslek seçiminde kişinin kendini anlayabilmesi çerçevesinde kendini tanıması ilk koşuldur. Yeteneklerin farkında olmak, ilgilerini amaçları doğrultusunda planlamak ve bunun sınırlarını çizmek ilk önemli koşuldur. Kendini bilen kişi amaçlarını belirledikten sonra başarı koşullarını belirlemeli, mesleğin avantajları ve dezavantajlarının bilincinde olarak hareket edebilmelidir. Farklı çalışma alanlarındaki firsatları görebilmeli, değerlendirebilmeli ve maddi olarak tatmin olmalıdır. Tüm bu çalışmalardan hareketle meslek seçiminde yalnız bir kriterin olmadığı, çeşitli faktörlerin söz konusu olduğu görülmektedir. Bireyin bu kriterleri dikkate alarak doğru kararlar vermesi, tüm faktörleri iyi analiz etmesi, meslek seçiminde rasyonel davranması açısından oldukça önemlidir [6].

Günümüzde hızlı gelişen bir sektör olarak havacılığın, meslek seçimi yapan öğrenciler arasında tercih edildiği görülmektedir. Küresel anlamda işleri kapsayan ve dünya çapında ulaşım ağını sağlayan bir sektör olarak havacılık sektöründe yer almak isteyen öğrenciler meslek seçimini yaparken biyolojik, ekonomik, sosyolojik vb. birçok etmenden etkilenmektedir. Bu çalışmada, havacılık bölümlerinde okuyan öğrencilerin meslek seçiminde etkili olan faktörlerin analizi araştırılmaya çalışılmıştır.

\section{Türkiye’deki Öğrencilerin Meslek Seçimi}

Eğitim dünyadaki sosyo-ekonomik sorunların evrensel olarak en önemli çözümüdür. Yoksulluk, cehalet, zihinsel yetersizlik, işsizlik, kötü devlet yönetimi, zayıf iletişim sistemi, açlık ve barınak gibi birçok sıkıntıya çare bulmak için uluslar ve bireyler eğitime bakmaktadır. Dünyanın her ülkesi, yaşam kalitesine ve toplumsal statüye önem vermektedir. $\mathrm{Bu}$ noktada öğrencilerin meslek seçiminin önemi ortaya çıkmaktadır. Meslek seçimi, öğrencilerin gelecek planlarını belirlemede yapacakları çok önemli seçeneklerden biri olmaktadır. Bu karar, hayatları boyunca onları etkilemektedir [8].

Öğrenciler için doğru meslek seçimi, öğrencilerin mesleki yaşamları ve gelecekteki başarılarını etkileyen kritik bir süreçtir [9]. Bu kritik sürecin nasıl olacağı, pek çok alternatif arasından nasıl karar verileceği önemlidir. Meslek seçiminin bir hayat biçimi seçmek olduğunu aktaran Vurucu, birçok insanın, seçmiş olduğu mesleği iyi analiz etmediği ve mesleğin hayat biçimini bilmediği için başarısız, verimsiz ve mutsuz olduğunu vurgulamaktadır [3].

Meslek seçimlerinde öğrencilerin, meslek ile ilgili her şeyi bilmeleri mümkün değildir. Öğrenciler bir mesleğin belli bir yönüne ilgi duyabilir, buna yoğunlaşabilir; ancak mesleğin diğer yönlerinin neler olduğunu anlayamayabilirler [10]. Örneğin, havacıllk bölümünde okuyan bir öğrenci uçaklara ve uzaya ilgisi olduğunu söyleyebilir. Ancak bu işi yapabilmesi için okulda ne kadar çalışması gerektiğini anlamayabilir. Ayrıca öğrenciler, ilgi alanlarında tüm işlere açık olmayabilirler.

Öğrenciler meslek seçimlerinde şu davranışları uygulayabilmelidir: (1) seçim süreciyle ilgilenmeli, (2) çalışma dünyasına karşı olumlu tutum geliştirebilmeli, (3) çevresinden bağımsız biçimde karar verebilecek duruma gelmeyi amaçlamalı, (4) seçimdeki olası faktörler arasından bazılarını tercih edebilmeli ve (5) seçim sürecini kavrayabilmelidirler [11]. Bunun için okulların en temel amaçları arasında, öğrencilerin kişilik özelliklerinin ve ilgi alanlarının ortaya çıkarılması; öğrencilerin meslekleri tanıyarak, hatta seçeceği mesleğe uygun kurumlara yöneltilmesi gerekmektedir [12].

Yanlış meslek seçimleri nedeniyle yaptıkları işlerden memnun olmayan kişilerin sayıları gün geçtikçe artmaktadır. Herhangi bir işte ücretli çalışanlar daha çok para kazanacakları işleri ararlarken, kendi işlerini kuranlar başarılı olmama endişesi yaşamaktadırlar. Bu sebeple meslek seçimi oldukça önem arz etmektedir [13]. 
Öğrencilere meslek seçiminde profesyonel destek verilmesi, Türkiye açısından değerlendirildiğinde, henüz yeterli yetkinlikle ve amaca uygun çalışan birimlerin olduğu söylenemez. Mevcut birimler genel olarak üniversite sonrası iş bulma konusunda yardımcı olmaktadır. Oysa meslek seçimi sürecinin üniversite öncesi verilmesi gerekmektedir [5].

Gelişimsel kariyer teorisyenlerinden Super (1990); Ginzberg, (1984); Gottfredson (1981); and Vondracek, Lerner, and Schulenberg (1986); ergenlik yıllarının gelecekteki kariyer seçiminin temelini oluşturduğunu vurgulamıştır. Ancak lise yıllarında aktif ya da pasif olmalarına bakılmaksızın tüm öğrencilerin yaptıkları tercihlerin, lisans ve lisans sonrası planlarıyla doğrudan ilgili olduğu açıklanmıştır [14]. Türkiye'de ise meslek seçiminde ilgili kurumların üniversite öncesi değil, üniversite sonrasında hizmet verdiği görülmektedir.

Meslek seçimini etkileyen faktörlerin Türkiye açısından değerlendirilmesine bakıldığında, öğrencilerin karar verme sürecinde ailesel ve çevresel etmenlerden daha fazla etkilendiğ görülmektedir. Bunlar arasında ailenin sosyoekonomik durumu, ebeveyn mesleği, ebeveynlerinin öğrenim durumu, eğitimin alındığ 1 bölge ve il, tercih edilen mesleğin gelişimi, mesleğin geleceğe dönük görünümü vb. gibi ailesel ve çevresel faktörler, meslek seçimi konusunda etkili olmaktadır [15].

Günümüzde Türkiye gibi birçok ülkede de öğrencilere yönelik herhangi bir kariyer eğitimi programı uygulanmamaktadır [16]. Gençlerin de kendi kariyerlerini kendi imkânları ile belirlediği açıktır. Günümüzde gençlerin gelecekle ilgili kaygılarının olduğu ve bunun meslek seçimini etkilediği, seçtikleri dallardan memnun olmadığı ve memnuniyetsizliğin mezuniyet sonrasında da devam ettiği gözlenmektedir [1].

\section{Türkiye'de Havacılık Eğitimi}

Sivil havacılık okulları, havacıllk sektörüne endüstriye yön verecek, endüstrinin gelişimini destekleyecek ve sektörde mesleki donanıma sahip, uluslararası standartlarda profesyonel personelleri yetiştirme misyonunu üstlenmiş ve havacıllı kültürünün gelişmesini sağlayan eğitim kurumları olarak tanımlanabilir [17].
Son yıllarda Türkiye'de sivil havacılık sektörünün hızlı gelişimi ile sektörde yetişmiş eleman ihtiyacı ortaya çıkmıştır. Buna paralel olarak havacılık bilgisi ve kültürüne sahip insan gücünün yetiştirilmesine ilişkin eğitimler de ayrı bir önem kazanmıştır [18]. Böylece sektördeki büyümeye paralel olarak sivil havacılık okulları ve yükseköğretimde havacılık alanında eğitim veren üniversite sayısında da önemli artışlar olmuştur [19]. Ayrıca havacılık ve eğitim arasındaki nedensel ilişki ve hava alanlarının ve hava hizmetlerinin ilişkisi de önem kazanmıştır [20].

Sivil havacılık sektöründe hızlı büyümeye paralel olarak sektörde faaliyet gösteren işletmeler, insan kaynağı ihtiyacını karşılamak için alanda eğitim veren üniversite mezunlarından ve açılan kurslar aracılığıyla eğitim alan adaylardan karşılama yoluna gidebilmektedir [21].

Türkiye'de havacılık sektöründe kalifiyeli personel ihtiyacının sağlanması amacıyla, Sivil Havacılık Genel Müdürlüğü (SHGM) ile Yükseköğretim Kurulu (YÖK) arasında iş birliği yapılmıştır [22]. SHGM ve YÖK arasında imzalanan işbirliği protokolüne göre, üniversitelerde sivil havacılığın tüm alanlarını kapsayacak şekilde ilgili bölümlerin açılması uygun görülmüştür. Bölümlere uygun müfredatların oluşturulması ve eğitim içeriklerinin düzenlenmesi kararlaştırılmıştır. $\mathrm{Bu}$ doğrultuda kalitenin arttırılarak belirli bir standardın sağlanabilmesi hedeflenmiştir. Yapılan işbirliği protokolü ile Türkiye'de havacılık sektöründe kalifiye personel ihtiyacının karşılanması, sivil havacılığın sürdürülebilir bir şekilde büyümesi ve üniversitelerde sivil havac1lı eğitimlerinin yaygınlaştırılması hedeflenmiştir. $\mathrm{Bu}$ doğrultuda yürütülen tüm çalışmalar sonucunda Pilotluk, Uçak Bakım Teknisyenliği, Kabin Hizmetleri, Sivil Hava Ulaştırma İşletmeciliği, Havacılık Yönetimi gibi branşlarda eğitim veren üniversitelerin ve meslek yüksekokullarının sayısında önemli bir artış sağlanmıştır [23].

Tablo 1'de Yüksek Öğretim Kurumu (YÖK) bünyesinde bulunan sivil havacılık bölümlerinin sayısı en fazla olan iki bölüm gösterilmektedir. 2019 y1lında Meslek Yüksekokulu bünyesinde Sivil Hava Ulaştırma İşletmeciliği ve Kabin Hizmetleri Bölümü hem devlet hem de vakıf üniversitelerinde en fazla olan bölümlerdir. 
Tablo 1: 2019 yılı Yüksek Öğretim Kurumu (YÖK) bünyesinde Sivil Hava Ulaştırma İşletmeciliği ve Kabin Hizmetleri Bölümü bulunan üniversitelerin sayıları

\begin{tabular}{ccc}
\hline & Devlet & Vakıf \\
\hline $\begin{array}{c}\text { Sivil Hava Ulaştırma } \\
\text { İşletmeciliği }\end{array}$ & 15 & 18 \\
Kabin Hizmetleri & 12 & 23 \\
\hline
\end{tabular}

\section{Araştırmanın Yöntemi}

Araştırmanın evreni, 2018-2019 öğretim yılında üniversitelerin havacılık bölümlerinde devam etmekte olan 253 öğrenciden oluşturmaktadır. Evrenin çalışma yapmaya olanak verecek büyüklükte ve yeterlikte olması nedeniyle, bütün evrene ulaşılması hedeflenmiştir. Anketlerin doldurulması sonucunda 253 öğrenci araştırmaya katılmıştır. Şubat 2019'de uygulanan ankete katılma oranı \% 81.2 olmuştur. Araştırmaya katılan toplam 253 öğrencinin 163'ü (\%64.4) erkek, 90’1 (35.6) kadındır.

Araştırmada veri toplama aracı olarak anket kullanılmıştır. Anketin geliştirilmesi sürecinde, alan yazında ayrıntılı ve teorik bir araştırma yapılmıştır. Öğrencilerin kariyer seçiminde etkili olan tüm faktörler tespit edilmiş ve bunlardan araştırmada yararlanılmıştır. İki bölümden oluşmakta olan ankette; birinci bölümde sosyodemografik değişkenlere ilişkin sorular yer alırken, ikinci bölümde ise öğrencilerin havacılığı meslek olarak seçmesinde etkili olan faktörleri saptamaya yönelik sorular yer almaktadır.

\subsection{Verilerin Analizi}

Veriler, Statistical Package for the Social Sciences (SPSS) 17.0 paket programı ile analiz edildi. Tanımlayıcı verilerde ortalama \pm standart sapma (minimum-maksimum değerler), yüzde (say1); gruplar arası karşılaştırmalarda Anova veya Kruskal Wallis testi kullanılmıștır.

\subsection{Araştırmanın Bulguları}

$\mathrm{Bu}$ bölümde öncelikle öğrencilerin kariyer seçiminde etkili olan etmenleri belirlemeye yönelik sorulara verdikleri yanıtların yüzdelik dağılımlarına bakılmıştır. Sonrasında ise meslek seçimi etmenlerine göre havacılığı ilk tercih olarak seçip seçmeme durumlarına ve çeşitli sosyodemografik değişkenlerin bu seçimdeki etkilerine bakılmıştır. Araştırmaya dahil olan 253 öğrencinin 194'ü (\%
76.7) ilk tercihinin havacılık bölümü olduğunu belirtmiştir. Öğrencilerin sosyo-demografik özelliklerine göre dağılımları tablo 2'de gösterilmiştir. Araştırmaya katılan 253 öğrencinin $\%$ 49,4'ü 17-19 yaş grubundadır. Katılımcıların \%35,6'sı kadın, \%64,4'ü erkektir. Katılımcıların ailelerinin \%93,7'si kentte yaşamaktadır ve ailenin \%66,4'ünün gelir aralığı 2000-4000 arasındadır. Ailenin eğitim durumunun okuryazar ve üzeri değeri \%85,8 iken, babanın eğitim değeri lise ve altı olarak \%81,4'dür. Öğrencilerin \%40,3'ü meslek lisesi mezunu iken, \%28,1'i Anadolu lisesi, $\% 31,2$ 'si diğer lise seçeneğiyle, düz lise mezunudur.

Araştırmaya katılan 253 öğrencinin meslek seçimini etkileyen faktörlere verdikleri yanıtların yüzdelik dağılımı Tablo 2' de sunulmuştur. Tablo 2'de öğrencilerin ilk sırada yer alan tercihlerinin yüzdelik dağılımları görülmektedir. Meslek yüksekokulunda havacılık bölümünü tercih etme nedenlerine ilişkin olarak öğrencilerin kendilerine sunulan çeşitli faktörlere, 7'li Likert skalasına göre puan vermeleri istenmiştir. Bu likert sisteminde (1) Tamamen katılmıyorum, (2) çoğunlukla katılmiyorum, (3) Kismen katılmiyorum, (4) $\mathrm{Ne}$ kat1liyorum, ne katılmiyorum, (5) Kismen katılıyorum, (6) Çoğunlukla katılıyorum ve (7) Tamamen katıliyorum şeklindedir. Buna göre havacılığ 1 tercih etmede öğrencilerin çoğunu etkileyen faktörün "havacıllk sektöründe kariyer yapma isteği” $(6,53)$ olduğu görülmektedir. Listenin ilk beş sırasında yer alan ve en çok etkilenen faktörlere sırasıyla bakıldığında şu faktörler dikkat çekmektedir. "havacılığın saygın bir meslek olduğunu düşünme" $(6,52)$, "havacıllğa ilgi duyma" $(6,45)$, “ekip çalışmasını sevme" $(6,18)$, "yeteneklerinin havacilığa uygun olduğunu düşünme" $(6,12)$ ve "havacilık sektöründe her zaman iş bulabilme düşüncesi” $(4,72)$. En düşük puanı alan sorular ise sırasıyla şu şekildedir. "Annenin ve babanın havacılık sektöründe kariyer yapmış, çalışmış/çalışan kişiler olması" $(1,28)$, "Bu mesleği seçmemi öğretmenlerim önerdi” $(1,91)$, "Ailenin İstanbul'da oturuyor olması" (2,04), "Bu mesleği seçmemde bu mesleğin getirdiği gelirin etkili olması" (2,19), "Bu mesleği seçmede arkadaşları önerisinin olması" $(2,25)$ 'dır. 
Tablo 2: Öğrencilerin Sosyo-Demografik Özelliklerine Göre Dağılım

\begin{tabular}{lccc}
\hline Özellikler & Grup & Sayı & Yüzde \\
\hline \multirow{2}{*}{ Cinsiyet } & Erkek & 163 & 35,6 \\
& Kadın & 90 & 64,4 \\
Okuduğu & Sivil Hava Ulaştırma & 98 & 38,7 \\
Bölüm & İşletmeciliği & & \\
& Kabin Hizmetleri & 103 & 40,7 \\
Ailenin & Diğer & 52 & 20,6 \\
Yaşadığı & Kent & 237 & 93,7 \\
Yer & Kırsal & 16 & 6,3 \\
& 2000 - 4000 & 168 & 66,4 \\
Aile Gelir & $4000-5000$ & 45 & 17,8 \\
& 5000 ve üzeri & 38 & 15 \\
Aile Eğitim & Okuryazar değil & 35 & 13,8 \\
Baba & Okuryazar ve üzeri & 217 & 85,8 \\
Eğitim & Lise ve altı & 206 & 81,4 \\
Bitirilen & Yüksek & 47 & 18,6 \\
Lise Türü & Meslek Lisesi & 102 & 40,3 \\
& Anadolu Lisesi & 71 & 28,1 \\
Hak & Diğer & 79 & 31,2 \\
Kazanılan & İlk Tercih & 194 & 76,7 \\
Sinav & İkinci Tercih & 56 & 22,1 \\
\hline
\end{tabular}

Tablo 3'de görüldüğü gibi birinci sırada önemli faktör olan "havacılık sektöründe kariyer" ikinci faktör olan "havacılığın saygın bir meslek olduğunu düşünme" ülkemizde üniversitelerde havacılık bölümlerinin açılmasıyla birlikte önem kazanmıştır. Havacılık mesleğinin seçiminde etkili olan üçüncü ve dördüncü faktör, "havacilığa ilgi duyma" ve "ekip çalışmasını sevme" olduğu görülmektedir. Öğrencilerin yaptıkları seçimlerde kendi istekleri doğrultusunda ve kendi yeteneklerini düşünerek yaptıklarını göstermektedir. Öğrencilerin meslek seçimini yaparken etkili olan diğer faktör "havacilık sektöründe her zaman iş bulabilme düşüncesi" de Türkiye'de havacılığın gelişimi ile ilgilidir. Türkiye'de artan havaalanı sayısı ve Türkiye'nin bayrak taşıyıcı havayolu şirketi olan Türk Hava Yolları'nın hızlı gelişimi ve dünyanın en büyük havaalanları arasına giren İstanbul Yeni Havalimanı'nın açılmasının etkisi oldukça önemlidir.

Tabloda önemli dikkat çeken diğer faktörler öğrencilerin meslek seçiminde en düşük puanı alan faktörlerdir. "Annenin ve babanın havacıllk sektöründe kariyer yapmış, çalışmış/çalışan kişiler

olması" havacılığın ülkemizde özellikle üniversitelerde okutulmas1 son on yılda önem kazanmıştır. " $\mathrm{Bu}$ mesleği seçmede ailenin etkisi olması" ve "Ailenin İstanbul'da oturuyor olması", "Bu mesleği seçmemde bu mesleğin getirdiği gelirin etkili olması", "Bu mesleği seçmede arkadaşları önerisinin olması" bulguları genel olarak öğrencilerin seçimlerini kendi istekleri doğrultusunda yaptıklarını göstermektedir. Buna ilaveten dışarıdan gelen baskı veya öneri gibi geleneksel faktörlerden fazla etkilenmedikleri görülmektedir.

Tablo 3: Havacılık Bölümü Öğrencilerinin Meslek Seçimlerini Etkileyen Faktörlere Yönelik yanıtların ortalamaları

\begin{tabular}{|c|c|}
\hline Etmen & Yüzde \\
\hline 1. Havacıllğa ilgi duyuyorum. & 6,45 \\
\hline $\begin{array}{l}\text { 2. Havacıllk sektöründe kariyer yapmak } \\
\text { istiyorum. }\end{array}$ & 6,53 \\
\hline $\begin{array}{l}\text { 3.Mesleğimin yeteneklerime uygun } \\
\text { olduğunu düşünüyorum. }\end{array}$ & 6,12 \\
\hline 4. Ekip çalışmasını seviyorum. & 6,18 \\
\hline 5. Okulda başarılı bir öğrenciydim. & 5,53 \\
\hline $\begin{array}{l}\text { 6. Mesleğimi seçerken aldığım notlar etkili } \\
\text { oldu. }\end{array}$ & 4,98 \\
\hline 7. Havacılık saygin bir meslektir. & 6,52 \\
\hline $\begin{array}{l}\text { 8. Bu mesleği seçmemde bu mesleğin } \\
\text { toplumdaki yeri etkili oldu. }\end{array}$ & 5,18 \\
\hline 9. Havacılık meslek olarak geliri yüksektir. & 5,81 \\
\hline $\begin{array}{l}\text { 10. Bu mesleği seçmemde bu mesleğin } \\
\text { getirdiği gelir etkili oldu. }\end{array}$ & 4,42 \\
\hline $\begin{array}{l}\text { 11. Benim için saygın bir iş yapmak önemli } \\
\text { değildir. }\end{array}$ & 2,19 \\
\hline 12.Havacılıkta iş garantisi vardır. & 4,62 \\
\hline $\begin{array}{l}\text { 13. Havacilık sektöründe her zaman iş } \\
\text { bulabilirim. }\end{array}$ & 4,72 \\
\hline $\begin{array}{l}\text { 14. Bu mesleği seçmemde, havacılık } \\
\text { sektörünün hızlı gelişimi etkili oldu. }\end{array}$ & 5,63 \\
\hline $\begin{array}{l}\text { 15. Bu mesleği seçmemde İstanbul'da } \\
\text { açılacak üçüncü havalimanı etkili oldu. }\end{array}$ & 4,69 \\
\hline $\begin{array}{l}\text { 16. Bu mesleği seçmemde, Türk Hava } \\
\text { Yolları'nın gelişimi etkili oldu. }\end{array}$ & 5,13 \\
\hline $\begin{array}{l}\text { 17. Yaptığım işin gelirinin yüksek olması } \\
\text { benim için önemli değildir. }\end{array}$ & 3,76 \\
\hline 18. Bu mesleği tercih etmemi ailem istedi. & 2,57 \\
\hline $\begin{array}{l}\text { 19.Ailemin beklentisi ve benim hakkımdaki } \\
\text { düşünceleri bu bölümü seçmemde etkili } \\
\text { oldu. }\end{array}$ & 3,21 \\
\hline $\begin{array}{l}\text { 20. Ailem İstanbul'da oturduğu için bu } \\
\text { bölümü seçtim. }\end{array}$ & 2,04 \\
\hline $\begin{array}{l}\text { 21.Annem ve babam havacılık sektöründe } \\
\text { kariyer yapmış, çalışmış/çalışan kişilerdir. }\end{array}$ & 1,28 \\
\hline $\begin{array}{l}\text { 22. Bu mesleği seçmemi öğretmenlerim } \\
\text { önerdi. }\end{array}$ & 1,91 \\
\hline
\end{tabular}


23. Bu mesleği tercih etmemi havacılık sektöründe çalışan tanıdıklarım önerdi. 24.Bu mesleği seçmemi arkadaşlarım önerdi.

Tablo 4'te havacılık bölümü öğrencilerinin meslek seçimlerini etkileyen etmenlere verdikleri yanıtların yüzde dağılımı ayrıntılı olarak gösterilmiştir. Öğrencilerin tamamen katılıyorum ve tamamen katılmıyorum şeklinde 7'li likert sisteminde verdikleri yanitlarda havacilik sektörünün Türkiye'deki gelişimiyle ilgili dikkat çeken sonuçlara ulaşılmıştır. Öğrencilerin \%74,7'si 'tamamen katıliyorum' ile "Havacılık sektöründe kariyer yapmak istiyorum" yanıtını verdiği görülmektedir. Türkiye'de havacılığın gelişimi, üniversitelerde havacılık bölümlerinin artması ile öğrencilerin havacılık sektörüne yöneldikleri söylenebilir. Öğrencilerin "Bu mesleği seçmemde, havacılık sektörünün hızlı gelişimi etkili oldu" $(\% 83,3)$, "Bu mesleği seçmemde, Türk Hava Yolları'nın gelişimi etkili oldu" $(\% 69,5)$ ve "Bu mesleği seçmemde İstanbul'da açılacak üçüncü havalimanı etkili oldu" $(\% 61,2)$ yanitları da öğrencilerin havacılık mesleğini seçmelerine yönlendiren faktörlerden en önemlileridir. Tablo'da öğrencilerin \%76,1'i 'tamamen katılıyorum' yanıtını vererek "Havacılığın saygın bir meslektir" olduğunu düşündükleri görülmektedir. Aynı zamanda öğrencilerin \% 56's1 'tamamen katılmıyorum' yanıtını vererek "Benim için saygın bir iş yapmak önemli değildir" ile bunu destekledikleri ortadadır.

Normallik ve eş varyanslı1ık şartları sağlanamadığından Anova yerine parametrik olmayan yöntemlerden Kruskal Wallis testinin yapılması uygun bulunmuştur.

Tablo 4: Havacıllk Bölümü Öğrencilerinin Meslek Seçimlerini Etkileyen Etmenlere Verdikleri Yanıtların Yüzde Dağılımı

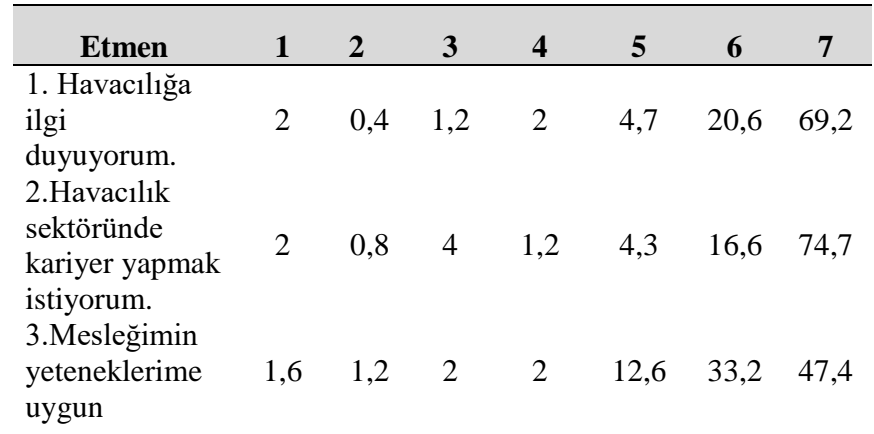

olduğunu

düşünüyorum.

4. Ekip

çalışmasını

seviyorum.

5.Okulda

başarılı bir

öğrenciydim.

6.Mesleğimi

seçerken

aldığım notlar

etkili oldu.

7.Havac1l1k

saygin bir

meslektir.

8.Bu mesleği

seçmemde bu

mesleğin

toplumdaki

yeri etkili oldu.

9. Havacilık

meslek olarak

geliri yüksektir.

10.Bu mesleği

seçmemde bu

mesleğin

getirdiği gelir

etkili oldu.

11. Benim için

saygın bir iş

yapmak önemli

değildir.

12. Havacilıkta

iş garantisi

vardir.

13. Havacilık

sektöründe her

zaman iş

bulabilirim.

14. Bu mesleği

seçmemde,

havacilik

sektörünün

hızlı gelişimi

etkili oldu.

15.Bu mesleği

seçmemde

İstanbul'da

açılacak

üçüncü

havalimanı

etkili oldu.

16. Bu mesleği

seçmemde,

Türk Hava

Yolları'nın

gelişimi etkili

oldu.

17. Yaptığım

işin gelirinin

yüksek olması

benim için

önemli

değildir.

18. Bu mesleği

tercih etmemi

ailem istedi.

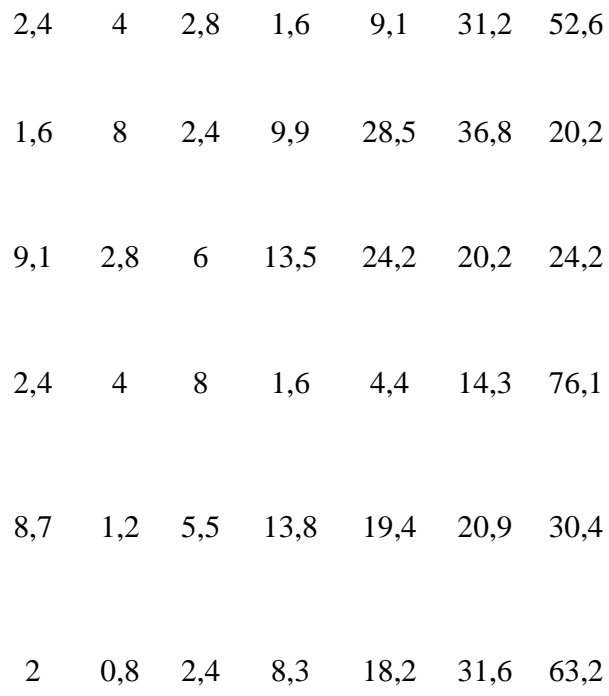

$\begin{array}{lllllll}49,6 & 12,7 & 6,3 & 10,3 & 10,3 & 4,8 & 6\end{array}$ 
19.Ailemin

beklentisi ve

benim

hakkımdaki düşünceleri bu

bölümü

seçmemde

etkili oldu.

20. Ailem

İstanbul'da

oturduğu için

bu bölümü

seçtim.

21.Annem ve

babam

havacılik

sektöründe

kariyer yapmış,

çalışmış/çalışan

kişilerdir.

22.Bu mesleği

seçmemi

öğretmenlerim

önerdi.

23.Bu mesleği

tercih etmemi

havacilık

sektöründe

çalışan

tanıdıklarım

önerdi.

24. Bu mesleği

seçmemi

arkadaşlarım

önerdi.

Yapılan analizlerde nomallik şartını sağlamayan değişken ölçeğinin parametrik olmayan yöntemler ile ölçülmesine karar verilmiştir. $\mathrm{Bu}$ sebeple Kruskal Wallis testi yapılmıştır. Tablo 5'de görüldüğg̈ gibi, öğrencilerin okuduğu bölümün sıralamalar ortalamalarının bitirilen lise türüne göre anlamlı bir farklılık gösterip göstermediğini belirlemek amaciyla yapılan Kruskal Wallis sonucunda öğrencilerin bitirilen lise türü gruplarının sıralamalar ortalamaları arasındaki fark istatistiksel olarak anlamlı bulunmamıştır.

Tablo 5: Okunulan Bölüm ölçeği puanlarının bitirilen lise türü değişkenine göre farklılaşıp farklılaşmadığını belirlemek üzere yapılan Kruskal Wallis Testi Sonuçları

\begin{tabular}{|c|c|c|c|c|c|c|}
\hline & $\begin{array}{l}\text { Bitirilen } \\
\text { Lise } \\
\text { Türüu }\end{array}$ & $\mathbf{n}$ & $\begin{array}{c}\text { Sira } \\
\text { Ortalaması }\end{array}$ & $X^{2}$ & $\begin{array}{l}\text { s } \\
\text { d }\end{array}$ & $\mathbf{p}$ \\
\hline \multirow{4}{*}{ 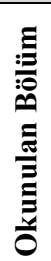 } & Meslek & 102 & 127,16 & \multirow{4}{*}{1,481} & \multirow{4}{*}{2} & \multirow{4}{*}{0,477} \\
\hline & $\begin{array}{l}\text { Anadolu } \\
\text { Lisesi }\end{array}$ & 71 & 133,12 & & & \\
\hline & Diğer & 79 & 119,70 & & & \\
\hline & Total & 252 & & & & \\
\hline
\end{tabular}

Tablo 6'da görüldüğü gibi, öğrencilerin okuduğu bölümün sıralamalar ortalamalarının hak kazanılan sınav türüne göre anlamlı bir farklılık gösterip göstermediğini belirlemek amacıyla yapılan Kruskal Wallis sonucunda hak kazanılan sınav türü gruplarının sıralamalar ortalamaları arasındaki fark istatistiksel olarak anlamlı bulunmamıştır.

Tablo 6: Okunulan Bölüm ölçeği puanlarının hak kazanılan sınav türü değişkenine göre farklılaşıp farklılaşmadığını belirlemek üzere yapılan Kruskal Wallis Testi Sonuçları

\begin{tabular}{|c|c|c|c|c|c|c|}
\hline & $\begin{array}{c}\text { Hak } \\
\text { Kazanılan } \\
\text { Sinav }\end{array}$ & n & $\begin{array}{c}\text { Sira } \\
\text { Ortalaması }\end{array}$ & $\mathbf{X}^{2}$ & sd & $\mathbf{p}$ \\
\hline \multirow{3}{*}{ 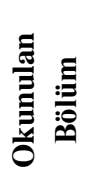 } & İlk tercih & 194 & 128,17 & & & \\
\hline & İkinci tercih & 56 & 116,24 & 1,367 & 1 & 0,242 \\
\hline & Total & 250 & & & & \\
\hline
\end{tabular}

Tablo 7'de görüldüğü gibi, öğrencilerin okuduğu bölümün sıralamalar ortalamalarının cinsiyete göre anlamlı bir farklılık gösterip göstermediğini belirlemek amaciyla yapılan Kruskal Wallis sonucunda cinsiyete göre grupların siralamalar ortalamaları arasındaki fark istatistiksel olarak anlamlı bulunmuştur. Havacılık bölümlerinde okuyan öğrencilerin erkeklerin ve kadınların arasındaki karşışş̧ırma yapılırken, erkek ortalamasının kadın ortalamasından daha yüksek olduğu görülmektedir.

Tablo 7: Okunulan Bölüm ölçeği puanlarının öğrencilerin cinsiyet değişkenine göre farklılaşıp farklılaşmadığını belirlemek üzere yapılan Kruskal Wallis Testi Sonuçları

\begin{tabular}{llcccccc}
\hline & Cinsiyet & $\mathbf{n}$ & $\begin{array}{c}\text { Sira } \\
\text { Ortalaması }\end{array}$ & $\mathbf{X}^{2}$ & sd & p \\
\hline & Kadın & 90 & 114,71 & & & \\
& Erkek & 163 & 133,79 & 4,55 & 1 & 0,033 \\
& Total & 253 & & & & \\
\hline
\end{tabular}

\section{Sonuçlar}

$\mathrm{Bu}$ araştırmada, üniversitelerin meslek yüksekokullarında havacılık bölümlerini tercih eden öğrencilerin bu mesleği tercih etme nedenlerini ortaya koymak amaçlanmıştır. $\mathrm{Bu}$ 
amaçla, 2018 - 2019 eğitim-öğretim y1lında eğitimine başlamış havacılık bölümü öğrencilerinin katılımıyla anket yöntemi kullanılmış ve anket verileri analiz edilmiştir. Araştırmada elde edilen önemli bulgular şunlardır:

- Meslek yüksekokulunda havacillk bölümlerinde en çok tercih edilen bölümler Sivil Hava Ulaştırma İşletmeciliği ve Sivil Havacılık Kabin Hizmetleri bölümleridir.

- Mesleği tercih eden erkek oranı kadınlara oranla daha yüksektir.

- Öğrencilerin mezun olduğu lise türünde meslek lisesi ilk sırada yer alırken; düz lise ikinci sıradadır. Meslek lisesinde çeşitli bölümlerden mezun olan öğrenciler havacılık bölümlerine yönelebilmektedir.

- Üniversitede havacıllk bölümlerine yerleşen öğrencilerin çoğunun ilk tercihidir.

- Öğrencilerin önemli bir k1smı, havacılığa ilgi duymakta ve bu mesleği seçmelerinde havacılık sektöründe kariyer yapmak istemektedirler.

- Öğrenciler mesleğin taşıdığ 1 iş avantajlarının bilincindedir. Kariyer, ücret ve kişisel gelişim gibi avantajlar öğrencileri cezbetmektedir.

- Öğrenciler mesleğin gerektirdiği bazı yeteneklere de sahip olduklarını düşünmektedir.

- Literatürde daha önce yapılan çalışmalarda görüldüğü gibi meslek seçiminde aile etmeni önemli bir aktördür. Ancak, bu araştırmada ailenin etkisi oldukça düşük çıkmıştır. Ayrıca başkalarının tavsiyelerini alma oranları da düşüktür.

- Türkiye'de havacılığın gelişimi, havacılık çalışmalarının artması, havaalanlarının açılması ile üniversitede havacılık bölümlerinin artması, öğrencilerin mesleği tercih etmelerinde ilk sırada yer almamaktadır.

Sonuç olarak öğrenciler, meslek seçiminde havacılı̆̆ 1 tercih ederken bilinçli hareket etmişlerdir. Ülkemizde havacılık bölümlerinde üniversiteye başlamalarıyla ilgili meslek seçimini etkileyen faktörlere ilişkin bir çalışma bulunmamaktadır. $\mathrm{Bu}$ araştırma üniversitede havacılık bölümlerinde okumakta olan öğrencilerin meslek seçimini etkileyen faktörleri belirlemek amacı ile tanımlayıcı ve kesitsel bir çalışma olarak yapılmıştır. Araştırma sonuçlarının meslek seçimini ve üniversite tercihlerini yapacak gençler için verimli olduğu düşünülmektedir. Özellikle de kararsız olan gençlerin meslek seçimine yönelik çalışmalara temel oluşturacağı düşünülmektedir. Havacılık mesleği bugünün popüler mesleklerinden biri olarak görülmektedir. Diğerlerine göre daha yeni olan sektörde bu çalışma, havacılığa ilişkin böyle bir araştırma literatürde bulunmamaktadır. $\mathrm{Bu}$ çalışmanın literatürde ilk olma özelliği önem arz etmektedir. Buna ilaveten araştırma sonuçlarının sektör paydaşları açısından da önemli bir bilgi kaynağı olacağ 1 tahmin edilmektedir. Türkiye'de bu alanda ön lisans programı ve fakültesi olan tüm üniversitelerin öğrencilerini kapsayacak şekilde araştırmanın genişletilmesi ileri bir araştırma konusu olarak önerilebilir.

\section{Kaynaklar}

[1] T. Sarıkaya ve L. Khorshid "Üniversite Öğrencilerinin Meslek Seçimini Etkileyen Etmenlerin İncelenmesi: Üniversite Öğrencilerinin Meslek Seçimi” Türk Eğitim Bilimleri Dergisi Bahar 2009

[2] V. Çurğatay "Üniversite Sinavina Girecek Öğrencilerin Meslek Seçimini Etkileyen Sosyo-Kültürel Faktörler (Malatya'daki Lise Son Sınıf Öğrencileri Uygulaması)" İnönü Üniversitesi Sosyal Bilimler Enstitüsü, Yükse Lisans Tezi, 2010

[3] F. Vurucu "Meslek Lisesi Öğrencilerinin Meslek Seçimi Yeterliliği Ve Meslek Seçimini Etkileyen Faktörler" Yeditepe Üniversitesi Sosyal Bilimler Enstitüsü, İstanbul 2010

[4] N. Çelik ve U. Üzmez "Üniversite Öğrencilerinin Meslek Seçimini Etkileyen Faktörlerin Değerlendirilmesi: Çağr1 Merkezleri Örneği” Elektronik Mesleki Gelişim ve Araştırma Dergisi (EJOİR) Cilt:2 Sayı:1 Mayıs 2014

[5] H. Can, U.G. Balcı ve K. Öngel "İzmir Katip Çelebi Üniversitesi Tip Fakültesi Birinci Sınıf Öğrencilerinin Meslek Seçiminde Etkili Faktörler” Euras J Fam Med 2013

[6] M. Pekkaya ve N. Çolak "Üniversite Öğrencilerinin Meslek Seçimini Etkileyen Faktörlerin Seçimini Etkileyen Faktörlerin Önem Derecelerinin AHP İle Belirlenmesi” 
International Journal of Social Science, Volume 6 Issue 2, p. 797-818, February 2013

[7] Brown Duane and associates "Career Choice and Devolopment" Jossey Bass, A Wiley Company, 989 Market Street, San Francisco, CA 94103-1741, 2002

[8] O.O. Salami ve O.O. Salami "The Factors Determining the Choice of Career Among Secondary School Students" The International Journal Of Engineering And Science (IJES) Volume 2 ||Issue 6, 2013

[9] A.K. Ahmed, N. Sharif ve N. Ahmad "Factors Influencing Students' Career Choices: Empirical Evidence from Business Students" IBIMA Publishing Journal of Southeast Asian Research, 2017

[10] D. Fizer "Factors Affecting Career Choices of College Students Enrolled in Agriculture" A Research Paper Presented for the Master of Science in Agriculture and Natural Resources Degree The University of Tennessee, Martin, 2013

[11] R. Özyürek ve M.A. Kılıç "Üniversite Öğrencilerinin Meslek Seçimi Kararlarında Kendilerine Yardım Eden Kaynakların Belirlenmesi" Türk Psikolojik Danışma ve Rehberlik Dergisi, Cilt 2, Sayı 17, 2016

[12] H. Bozgeyikli "Meslek Kararı Verme Yetkinlik Ölçeğinin Geliştirilmesi” Selçuk Üniversitesi Sosyal Bilimler Dergisi, 2009

[13] S. Deniz "Bireyin Meslek Seçimini Etkileyen Kaynaklar: Yeni Teknolojilerden İnternet" Muğla Üniversitesi SBE Dergisi, Güz, Sayı 6,2001

[14] H.K. Paa ve E.H. McWhirter "Perceived Influences on High School Students' Current Career Expectations" The Career Development Quarterly, 49 (1), 2000

[15] E. Sertel, H. Yıldırım ve S.Ö. Akyol "Meslek Yüksek Okulu Öğrencilerinin Okul Tercih Sebepleri ve Uyum Durumları: Sivrihisar Örneği” Ulusal Meslek Yüksekokulları Sosyal Ve Teknik Bilimler Kongresi, Mehmet Akif Ersoy Üniversitesi, Burdur, 2017
[16] G. Genç, A. Kaya ve M. Genç "İnönü Üniversitesi Tıp Fakültesi Öğrencilerinin Meslek Seçimini Etkileyen Faktörler” İnönü Üniversitesi Eğitim Fakültesi Dergisi, Güz 2007, 8(14)

[17] K. Kiracı Kasım ve Ü. Bayrak Ümran "Sivil Havacılık Lisans Mezunlarının İstihdam ve Kariyer Durumları Üzerine Bir Araştırma" e -International Journal of Educational Research Volume: 5 Issue: 2 pp 67-88, 2014

[18] M.H. Uncular "Havacilık Alanında İnsan Kaynağ1 Yetiştirme ve THY Akademinin Uluslararası Eğitim Akreditasyonları" T.C. Maltepe Üniversitesi Sosyal Bilimler Enstitüsü, İşletme Anabilim Dalı, Yüksek Lisans Tezi, 2014

[19] K. Kirac1, Ü. Bayrak ve Y. Kurt "Türkiye'deki Sivil Hava Ulaştırma İşletmeciliği Bölümü Öğretim Eleman ve Yardımcılarının Akademik Özgeçmişlerinin Nicel Görünümü” UHAT 2013 / II. Ulusal Havacilık Teknolojisi ve Uygulamaları Kongresi / İzmir, 2013

[20] G. Solvoll, T. Hanssen, E.Sandberg "Importance of Aviation in Higher Education” Business School, NO-8049, Bodo, Norway

[21] N. Karaağaçoğlu "Sivil Havacılık Alanındaki Sektör Beklentileri ve İstihdam Taleplerinin Akademik Programların Oluşturulmasında Etkisi: YÖK-SHGM Sivil Havacılık Eğitim Komisyonu Çalışmaları" T.C. Maltepe Üniversitesi Sosyal Bilimler Enstitüsü, Halkla İlişkiler ve Tanıtım Anabilim Dalı, Yüksek Lisans Tezi, 2015

[22] Gülten Genç, Kaya Alim ve Genç Metin "İnönü Üniversitesi Tıp Fakültesi Öğrencilerinin Meslek Seçimini Etkileyen Faktörler" İnönü Üniversitesi Eğitim Fakültesi Dergisi, 8(14), 49-63, 2007

[23] SHGM, "SHGM" http://web.shgm.gov.tr/tr/haberler/1822shgm-ile-yok-arasinda-isbirligi-protokoluimzalandi [Erișim Tarihi: 15-Temmuz-2019] 